\title{
Managerial Perception of Human Capital, Innovations, and Performance: Evidence from Banking Industry
}

\author{
Nela Milosevic, Marina Dobrota, Veljko Dmitorvic, Sladjana Barjaktarovic-Rakocevic
}

\author{
University of Belgrade, Faculty of Organizational Sciences \\ Jove Ilica 154, 11000 Belgrade, Serbia \\ E-mail.nela.milosevic@fon.bg.ac.rs; marina.dobrota@fon.bg.ac.rs; veljko.dmitrovic@fon.bg.ac.rs; sladjana@fon.bg.ac.rs
}

cross $^{\text {ref }}$ http://dx.doi.org/10.5755/j01.ee.32.5.26032

\begin{abstract}
This paper aims to examine the relationship between the managerial perception of human capital, innovations, and bank performance. We specifically sought to examine the influence of human capital on bank performance, by introducing the factors of innovation speed and quality. The study was taken in the Serbian banking industry, with the focus on the perception and the viewpoint of CEOs and general managers of different departments. We used a two-phase survey to design the questionnaire and the correlation and regression analyses to examine our hypotheses. Our findings propose that, from managers' perspective, human capital is critical to the success of banks, and that innovation speed is more influential than its quality. The backward multiple regression model shows that human capital and innovation speed account for $67.5 \%$ of the variability of the bank performance. The findings of this research can contribute to bank management policies by revealing how to enhance bank performance by focusing on human capital and innovation agility and readiness. The proposed research model could potentially be implemented in other sectors and industries to hopefully endorse the significance of the detected relationships.
\end{abstract}

Keywords: General Managers; Perception; Banking Industry; Performance; Human Capital; Innovation Speed and Quality.

\section{Introduction}

In a contemporary business environment, intellectual capital is acknowledged as a valuable contribution to performance. Among other benefits, organizations that disclose high-quality intellectual capital have a better chance for innovations and R\&D improvements (Soewarno $\&$ Tjahjadi, 2020). One of the major aspects of intellectual capital is human capital (Asiaei \& Jusoh, 2017; Liu, 2017), which could be presented as an organization's entire available knowledge stock (Campbell, Coff \& Kryscynski, 2012). Bearing in mind that we live in an information society where people are the main resource of organizations (Ozkan, Cakan \& Kayacan, 2017), it would not be possible to achieve significant improvements in business or performance without experts.

This research aims to determine how CEOs and general managers of different departments perceive the association between human capital and performance, with a specific focus on the banking industry. Respectively, the objectives of the study are (1) to analyze the general managers' perception of the human capital influence on bank performance and (2) to identify their observation of the relationships between human capital, innovations, and performance within the banking industry. We presume that innovations are among the critical components leading to high-level performance and competitive advantage. It was pointed out that innovations were among companies' most important advantages and drivers for success (Cornaggia, Mao, Tian \& Wolfe, 2015), as well as that the top-quality performance and innovations were crucial for economic growth (Cabrilo, Uzelac \& Cosic, 2009).
This study offers two relevant contributions in the area of human resource management. First, it presents the empirical mechanism by which human capital and innovations successfully enhance bank performance, with respect to managerial perception of these concepts, where human capital has both direct and indirect influence on bank performance through its effects on innovation speed and quality. Second, it highlights an important role played by the human capital in the process of innovation, documented as the main determinant of the performance in today's banking industry.

The relationship between human capital and performance was discussed in a number of papers, but this research differs from existing work in several ways. We particularly focus on mediation effects of innovation speed and quality within the banking industry and their influence on performance. Also, it has been shown that human capital is defined as one of the key innovation factors in different business environments (Delgado-Verde, Martinde Castro \& Amores-Salvado, 2016; Rezende, Correia \& Gomes, 2017) and that innovations signal future opportunities and represent the "pinnacle success factor" in the corporate world (Rajapathirana \& Hui, 2018), but we particularly focus on the shortage of the empirical evidence from the banking industry. Additionally, we call for research in the banking industry in developing countries, arguing that quality innovation management is one of the most important preconditions for technological, economic, and sociological improvement.

The results presented by Hanley, Suter, and Cocheo (1997) suggest that financial indicators do not reveal the strategies that lead to top performance. Traditional performance rankings such as return on equity (ROE) and 
return on assets (ROA) are not sufficient indicators of success anymore. Moreover, Roy and Shijin (2018) find that aggregate market and human capital are the strongest predictors of asset returns in different economies. In our study, we measure bank performance through quality, cost management, responsiveness, productivity, profitability, and customer satisfaction (Wang \& Wang, 2012). The measures used in this research are predominantly based on the perceptions of CEOs and general managers regarding the state and the capacity of their banks. The study was conducted in Serbia, covering the entire Serbian banking industry. We tested our assumptions in the banking industry since banks are one of the most innovative organizations worldwide (Zaleska \& Kondraciuk, 2019). Daily, the banking industry faces numerous risks which is why banks have to innovate constantly, especially in terms of communication channels and products (Espinoza-Loayza, Salas-Tenesaca \& Samaniego-Namicela, 2019).

To shed light on the presented topic, we developed a model that is based on the literature review of relations among human capital, bank performance, and innovations.

\section{Theoretical Background}

\section{Human Capital}

According to Becker (1975), human capital is the key driver behind the organizational performance. Therefore, employees can be considered crucial for performance development and innovative changes within organizations. Lopez-Cabrales, Valle, and Herrero (2006) find that employees with specific knowledge, skills, and abilities are positively associated with an organization's competitiveness and efficiency. For example, international work experience can be observed as a human capital element that makes employees more profitable to organizations (Schmid \& Altfeld, 2018). An emerging body of work shows that human capital is a fundamental resource that helps organizations maintain their competitive advantage (Chowdhury, Schulz, Milner \& Van De Voort, 2014; Sakalas \& Liepe, 2013) and that it has a positive impact on business activities and results (Nguyen, 2020). Additionally, employees' competencies can be defined as "the capacity of an individual to be successful according to (in)formal criteria, to handle certain situations and complete a certain task" (Otoo, 2019). Besides, it was pointed out that improvements in human capital development and management might lead to improved organizational performance (Aledo Ruiz, Gutierrez, Martinez-Caro, \& Cegarra-Navarro, 2017). For instance, Nienaber and his colleagues found that innovations and organizational success result from both the learning orientation that people have and external network ties (Nienaber, Schewe, Zamantili Nayir \& Holtgrave, 2019).

The influence of human capital on the firm's innovation activities has been a subject of studies that analyze innovations within organizations. For instance, Ahuja and Katila (2001) point out that an increase in knowledge base will improve human capital quality, leading to better organizational performance. The relationship between different leadership development practices and organizational performance was analyzed, using human capital as a mediator variable (Subramony, Segers, Chadwick \& Shyamsunder, 2018), with the inspection of the economic impact of investments in employees and consequences for organizational performance. It was found that intellectual capital usage efficiency positively affects the financial performance of banks (Meles, Porzio, Sampagnaro \& Verdoliva, 2016) and that the growth in market performance and financial performance are tightly linked to human capital (Huselid, 1995).

Human capital is part of intellectual capital, although there is no consensus upon the components of intellectual capital in terms of theory and research. It can be defined as the collective knowledge, skills, and abilities of employees (Sirmon \& Hitt, 2009). Moreover, human capital is a strategic resource in companies, and it is comprised of knowledge, capabilities, and skills accumulated by employees through education, learning, and experience (Chen \& Huang, 2009). Human capital is strongly related to performance and is one of the crucial factors for achieving goals and financial outcomes (Crook, Todd, Combs, Woehr \& Ketchen, 2011; Jiang, Lepak, Hu \& Baer, 2012). The knowledge management implementation improves resource efficiency and effectiveness and, consequently, an organization's performance and competitiveness (Cebi, Aydin, \& Gozlu, 2010). It is proved that intellectual capital contributes to the profitability, efficiency, and earnings per share of organizations (Firer \& Stainbank, 2003; Milosevic, Dobrota \& Barjaktarovic Rakocevic, 2018; Pew Tan, Plowman \& Hancock, 2007). Yen (2013) analyzed how human capital affects innovative capability in banks, while Gurbuz and Mert (2011) state that human resources receive increasing recognition worldwide, related to the strategy and performance measurement. The role of human resource management (HRM) practice in bank performance was analyzed using data envelopment analysis (Masum, Azad, \& Beh, 2016), showing that HRM practices should be improved to deal with both bank modernization and competitive challenges. Additionally, KondratiukNierodzinska (2016) indicates that human resources are the crucial component for Central and Eastern European countries' development, especially if those countries want to catch up to their highly developed European counterparts.

\section{Innovations}

Employees' knowledge and the organizational climate that cultivates innovations among employees are crucial for achieving a competitive advantage regarding innovations (Prokop \& Stejskal, 2017; Shanker, Bhanugopan, van der Heijden, \& Farrell, 2017). Literature shows that new venture firms pursue a strategy of innovation to enhance their competitive advantage and performance (Shinkle \& Suchard, 2019; Terziovski, 2010). A great deal of attention is paid to the creation of new high technologies, increasing the level of development in regards to science and innovations (Amrin \& Nurlanova, 2020). A positive organizational climate should be one of the crucial motivating factors for employees to give their best in order to reach targets and perform better than their competitors. For example, earlier studies emphasize that innovative culture positively influences organizational innovations, which ultimately fosters long-term 
competitiveness (Santos-Vijande, López-Sánchez, \& González-Mieres, 2012). Additionally, the high level of competition is one of the crucial determinants of the innovative character of banking activities (Zaleska \& Kondraciuk, 2019). Therefore, banks are encouraged to use new technologies to maintain their market position. Newer literature investigates how the exploitative and exploratory innovations affect firms' competitive advantages, showing that the exploitative innovations positively influence smaller or medium firms' export performance, while it is not the case with exploratory innovations (Ribau, Moreira, \& Raposo, 2019). Moreover, managers and employees need to be aware that innovations are significant for their company because otherwise, they would not be patient and motivated to overcome all obstacles and to be innovative (Shankar \& Ghosh, 2013). Developing innovative solutions is not an easy task. People cannot expect innovations to just happen, and devotion and teamwork can also bring a positive effect to innovations and performance.

Generally speaking, innovations can be divided into two main groups: radical and incremental (Schumpeter, 1934). Radical innovations include a completely new product or process, while incremental changes continuously make improvements and help organizations reach a more competitive position on the market. Another way to classify innovations is into: (a) technical, which refers to new processes, products, or services, and (b) administrative, which includes new procedures, policies, and organizational forms (Damanpour, 1991). Kahn (2018) defines innovation through three different things: an outcome, process, or a mindset. Innovation as a mindset refers to the innovativeness of individual members of the organization. Moreover, the development of an innovative way of thinking strongly depends on organizational culture and internal support (Kahn, 2018; Ucar, 2018). There is a growing body of literature that examines innovative organizations' behavior. Solow (1957) analyzes the relationship between technological change and business performance, while others, such as Cabagnols and Le Bas (2002), define determinants of organizations' innovative behavior.

Innovation capacity refers to an investment in several aspects: knowledge of employees, management methods, culture, and internal and external relationship networks (Santos, Basso, Kimura, \& Kayo, 2014). Through this paper, we will mainly focus on the first factor, as it is the most important for this research.

\section{Innovation Speed and Quality}

Wang and Wang (2012) point out that the key variables for measuring innovation are its speed and quality. They define innovation speed "as the time elapsed between (a) an initial development, including the conception and definition of innovation, and (b) the ultimate commercialization of a new product or service into the marketplace" (Wang \& Wang, 2012, p. 8900). Technological development and shorter product lifecycles foster companies to innovate faster (Heirman \& Clarysse, 2007).

Innovation quality can be measured by comparing results with the potential of products, processes, or service innovations (Haner, 2002). Moreover, Haner (2002) states that innovation quality can be analyzed through a product/service domain, a process domain, and an enterprise domain. Wang and Wang (2012) suggest that, concerning products or services, innovation quality may be defined through variables like amount, effectiveness, features, reliability, timing, costs, complexity, innovation degree, and value to the customer.

Additionally, Tabacco (2015) suggests that the competition in the banking industry does not spur innovations. However, competition does exert a strong influence on the relationship between performance and innovations: "the more valuable, imperfectly imitable, and rare innovations are, the higher performance will be" (Garcia-Morales, Llorens-Montes, \& Verdú-Jover, 2008, p. 15). Innovation speed and quality, fostered by employees' skills, experience, knowledge, and creativity, have a strong impact on performance within the banking industry.

\section{Performance}

The concepts of human capital and innovations within the banking industry allow for evaluating performance and comparison with the key competitors. Rue, Byars, and Ibrahim (2012) argue that performance evaluation indicates how employees define their work. Earlier research found a positive relationship between performance and human capital within audit firms (Chen, Hsu, Huang \& Yang, 2013). Samagaio and Rodrigues (2016) also emphasize the importance of human capital for the performance of audit firms and point out that multiple combinations of human capital attributes lead to high performance. Additionally, worldwide companies make large investments in research and development in order to be innovative with high-performance results (Rouvinen, 2002).

Nowadays, digital technology and fintech competitors have changed financial system stability (Vives, 2019). In recent years, the banking industry moved from traditional to modern, which pays attention to technological and innovative solutions and human capital. Jokipii and Monnin (2013) define the stability of the banking industry as the "banking sector's probability of default", influencing economic factors such as GDP growth. Additionally, the stability of the banking industry is tightly linked to equity bubbles which encourage firms to invest in innovations and promote growth (Wang, Chen \& Xiong, 2019). Therefore, banking stability can be considered as a precondition for investments in innovations. In October 2013, the European Commission (EC) defined a new indicator for measuring the EU's progress in meeting the goals of the Europe 2020 Strategy (European Commission, 2018). It is a combination of four individual indicators: (1) patent applications, (2) the economic significance of knowledge-intensive sectors, (3) trade performance of knowledge-intensive goods and services, and (4) significance of fast-growing firms in innovative sectors (Janger, Schubert, Andries, Rammer, \& Hoskens, 2017). The banking industry is knowledge-intensive and continuously focused on innovation speed and quality, aiming to improve performance. Most commonly used key performance indicators in the banking industry refer to 
(Wu, 2012): profitability (e.g. return on investment capital, return on equity, return on assets), asset utilization (e.g. asset turnover), leverage ratio (e.g. total debt/total equity, fixed assets/total equity), liquidity ratio (e.g. deposits/total assets), growth ratio (e.g. net sales growth, EPS growth), and stock performance (e.g. P/E ratio, dividend pay-out).

The banking industry of countries in the South-Eastern European region suffers from significant inefficiency differences. The important characteristic of these countries is that foreign banks and banks with major foreign ownership are associated with higher efficiency (Staikouras, Mamatzakis \& Koutsomanoli-Filippaki, 2008). Some authors emphasize a strong link between competition and bank efficiency (Koutsomanoli-Filippaki, Margaritis \& Staikouras, 2009). It has been shown that productivity in this region has improved because of institutional and structural reforms. The banking industry in Bosnia and Herzegovina has been under reform for several years due to the political and economic situation. The main aim of the reform was to create a more competitive environment under the market conditions (Cinjarevic, Tatic \& Avdic, 2010). Nowadays, competition is one of the main challenges for the banking industry. For instance, Romanian banks introduce innovations to protect their market shares (Stoica, Mehdian \& Sargu, 2015). In developing countries within Europe, such as Serbia, Croatia, Slovenia, and others, the environment for innovations requires "the existence of rule of law, gender equality, economic and political stability, and access to information" (Ege \& Ege, 2019, p. 451).

In this study, we propose a research model that determines the path from human capital to bank performance, reflecting the innovation speed and quality impact on performance. The problem is of practical importance because banks are investing considerable time, money, and effort in fostering employees' knowledge, in order to manage innovations at the best possible level, which would lead to higher bank performance and success.

\section{Conceptual Framework and Hypotheses}

Human capital can be seen as a critical economic factor and reliable predictor of the performance of an organization (Cooper, Gimeno-Gascon \& Woo, 1994; Fitzsimons, 2017). Moreover, a growing body of literature shows that investing in human capital can lead to higher performance (Crook et al., 2011; Subramony, Krause, Norton \& Burns, 2008). Based on the above findings, and having in mind the structure of our research, where we examine the managerial perception of the given concepts in the banking industry, we develop the first hypothesis:

H1: The perception of human capital has a positive influence on the perception of bank performance.

Further on, the findings from Prajogo and Oke (2016) show that human capital significantly influences innovations, consequently having a positive impact on performance. These authors also suggest that human capital is tightly linked to the creativity and development of new ideas. Therefore, human capital results in innovation advantage for organizations. The environment that supports innovations vastly depends on people (Hall \&
Mairesse, 2006). Ucar (2018) shows that local creative culture has a very important role in corporate innovations and finds that a strong local creative culture increases the number of innovation outputs. The relationship between human capital and innovation becomes stronger within a very dynamic environment (Prajogo \& Oke, 2016). Furthermore, Redding (1996) presents a model where employees invest resources in human capital and organizations invest resources in research and development departments in order to improve their quality, thus creating the economy's long-run rate of growth. Marvel and Lumpkin (2007) argue that radical innovations usually depend more on individual knowledge rather than organizational processes, while Baumol (2005) suggests that independent entrepreneurs are more likely to develop high-quality innovations. Therefore, we develop the second hypothesis:

H2: The perception of human capital has a positive influence on innovation within the banking industry.

Based on the work of Wang and Wang (2012), in our research, we monitor the innovation effects through innovation quality and speed. These concepts could be observed as mediators between human capital and performance. By following Wang and Wang (2012), we define innovation speed as the time between the initial idea and the moment when a product/service finds its place on the market. Nowadays, organizations are under pressure to innovate faster, and innovation speed indeed is a vital element in terms of competitiveness. Wang and Wang (2012) state that innovation speed yields better performance. With new technological solutions, we believe that innovation speed becomes an important factor not only for competitive advantage but also for superior performance in the banking industry.

On the other hand, innovation quality is defined as an "aggregated innovation performance in three different domains: product/service, process, and enterprise" (Haner, 2002, p. 31). Moreover, innovation quality can be defined through variables such as amount, effectiveness, features, reliability, timing, costs, complexity, innovation degree, value to the customer, etc. (Wang \& Wang, 2012). Cozzarin (2004) finds support for the reasoning that innovative organizations have higher performance. He shows that market share, total employment, and price-cost margins are all increasing in innovation quality. The examination of these articles resulted in the development of the third hypothesis:

H3: The perception of innovations has a positive influence on the perception of bank performance.

Based on the previous literature review, our research considers human capital as a basic factor, while innovations are considered as a complementary factor. The structure of the research is reflected in Figure 1. This figure depicts the suggested research, including the four main variables: human capital, innovation speed, innovation quality, and bank performance as a dependent variable. The figure also illustrates the potential influence of years that the bank has been doing business in Serbia, as well as the number of employees. 


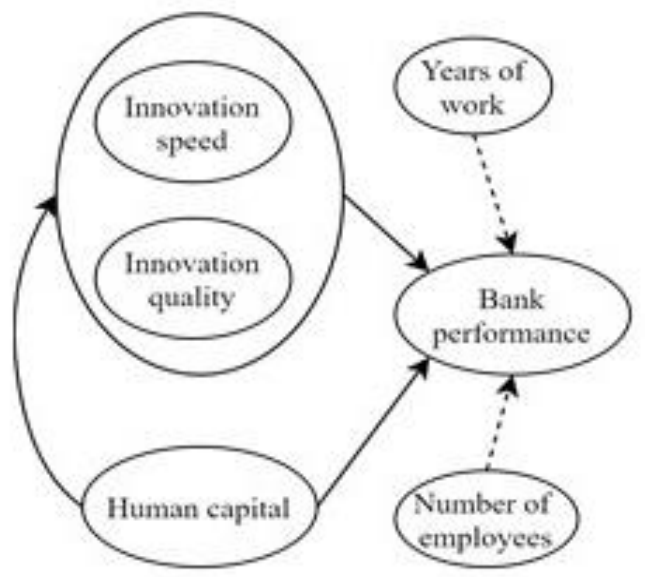

Figure 1. Conceptual Framework of the Research

The conceptual framework of the research depicts the proposed hypotheses, while the measured variables will be presented and explained in detail in the next section, as well as in Table 1 and Table A1. The interrelationships among the measured variables and their theoretical meaning are justified in the literature (Garcia-Morales et al., 2008; Gkypali, Filiou \& Tsekouras, 2017; Santos et al., 2014).

\section{Methodology}

Our study was focused on the perceptions and understandings of CEOs and general managers from different departments in the banking industry. In Serbia, there is a total of 28 domestic and foreign banks operating in a fairly developed financial market, which is also characterized by robust competition and considerable political and economic instability.

The organizational structure of a bank is a matrix - it brings together managers and employees from various departments to work towards the goal accomplishments. Bankers from different sectors are involved in specific projects according to their field of expertise. We have chosen the banking industry for our study because of the constant need for innovative solutions and in order to achieve high performance we must look at the importance of the relationship between employees and clients. This study mainly includes the sectors of strategic marketing, retail, and project management in the Serbian banks. For the purpose of the research, we have collected the amount of 32 CEOs and general managers that are employees in 28 surveyed banks.

The measures of the components of our study, given in Figure 1, were mainly adjusted from the scales in the literature and were appropriately modified with respect to the Serbian banking industry and the perceptions of the general managers. We used a two-phase survey to design the questionnaire. Namely, to ensure the legibility of the designed questionnaire, in the first phase, it was subjected to a pilot test that consisted of interviews with three experts from the banking industry and two persons with management degrees from the University of Belgrade, the largest university in Serbia. Following their suggestions and comments, the questionnaire was modified accordingly, which resulted in the final questionnaire used to collect the data. The overview of the survey variables that were examined in this research is shown in Table 1.

Table 1

\section{Research Variables, Descriptive Statistics, Cronbach's Alphas, and Pearson Correlation Coefficients}

\begin{tabular}{|l|c|c|c|c|c|c|c|c|c|}
\hline Variables & Mean & SD & Cronbach's alpha & $\mathbf{1}$ & $\mathbf{2}$ & $\mathbf{3}$ & $\mathbf{4}$ & $\mathbf{5}$ & $\mathbf{6}$ \\
\hline 1 - Human capital & 3.83 & 0.633 & 0.867 & - & & & & & \\
\hline 2 - Innovation speed & 3.31 & 0.741 & 0.813 & $0.502^{* *}$ & - & & & & \\
\hline 3 - Innovation quality & 3.54 & 0.737 & 0.887 & $0.514^{* *}$ & $0.737^{* * *}$ & - & & & \\
\hline 4 - Years of work & 36.38 & 5.740 & - & 0.236 & -0.011 & 0.138 & - & & \\
\hline 5 - Number of employees & 1351.59 & 89.99 & - & -0.119 & -0.307 & -0.067 & 0.213 & - & \\
\hline 6 - Bank performance & 3.41 & 0.667 & 0.904 & $0.708^{* * *}$ & $0.736^{* * *}$ & $0.625^{* * *}$ & -0.003 & -0.251 & - \\
\hline
\end{tabular}

Note: *Sig. at the level $\mathrm{p}<0.05 ; * *$ Sig. at the level $\mathrm{p}<0.01 ; * * *$ Sig. at the level $\mathrm{p}<0.001$; Adjusted from literature (Wang, Sharma, \& Cao, 2016; Wang, Wang, \& Liang, 2014; Wang \& Wang, 2012)

The five-point Likert scales were used throughout the questionnaire. We measure the Human capital scale using items from Wang, Sharma, and Cao (2016). This scale has a good internal consistency, with a reported Cronbach's alpha coefficient of 0.867 (Cortina, 1993; DeVellis, 2011; Kline, 2013). The items we used refer to the work experience of employees, their professional skills and creativity as well as the training programs provided by the bank (Table A1). The Innovation speed scale counts four, while the Innovation quality scale counts five variables (Table A1), and they both have a good internal consistency with a Cronbach's alphas of 0.813 and 0.887 , respectively. In order to measure the innovation speed, we used the scale from Wang and Wang (2012). The scale contains questions referring to the speed of coming up with novel ideas, product launching, new processes, and problem solutions. We developed an innovation quality scale by retaining five items from Wang and Wang (2012) that should capture the quality of novel ideas, product launching, new processes, and problem solutions.

To measure the bank performance, we adopted the scale from Wang, Sharma, and Cao (2016). The Bank performance scale counts eight variables (Table A1) and it has an excellent internal consistency with a Cronbach's alpha coefficient of 0.904 . The original scale measures separately operational and financial performance. We decided to use all five items that refer to operational performance and to ask only about managers' perceptions of profit, profit growth, and fund management since financial measures are very sensitive issues, especially within the banking industry. The detailed scales and their components are presented in Appendix A.

Apart from the defined scale measurements, we also included the measure of durability - years the bank has 
been doing business in Serbia (Years of work), as well as the number of employees in the observed banks (Number of employees). We included these variables in order to examine whether the CEOs' and general managers' opinions are influenced by the size of the bank and/or its prestige. The absence of differences is consistent with the claim of Armstrong and Overton (1977).

Since all the answers in the questionnaire were collected simultaneously, regardless of the dependent or independent variables, we tested if the responses in our research were faced with the common method bias (CMB) (Podsakoff, MacKenzie, Lee \& Podsakoff, 2003; Podsakoff, MacKenzie \& Podsakoff, 2012). CMB is observed through the presence of a systematic variance (Bagozzi \& Yi, 1990) that can inflate or deflate a relationship among variables (Doty \& Glick, 1998) which can lead to unsound conclusions. We wanted to check whether the variations in responses are caused by the instrument rather than the actual predispositions of the respondents. To do so, we performed Harman's unrotated single factor test. The test showed that a single factor accounts for $48.625 \%$ of all the variability in the model. Since it is less than $50 \%$, our research instrument is showed to be free from significant common method bias effects, and therefore, there is no substantial CMB present in the data.

\section{Results}

The interdependence among managerial perspective of the human capital, innovation speed, innovation quality, and bank performance were determined through correlations and the multiple regression model. The Pearson correlation coefficients are shown in Table 1.

The study identified a strong positive correlation between human capital and bank performance $(r=0.708$, $\mathrm{p}<0.001)$. This result goes in favor of the first hypothesis that human capital is positively correlated with bank performance. Moreover, human capital is positively correlated to innovation speed and innovation quality $(\mathrm{r}=0.502, \mathrm{p}<0.01 ; \mathrm{r}=0.514, \mathrm{p}<0.01$, respectively), which inclines the second hypothesis of the research.

A strong correlation also exists between innovation speed and bank performance $(r=0.736, p<0.001)$, as well as between innovation quality and bank performance $(\mathrm{r}=0.625, \mathrm{p}<0.001)$, which is in line with the third hypothesis. The relationships between bank performance as the dependent variable and human capital, innovation speed, and innovation quality as predictors are presented in Figure 2. From the general managers' perspective, the single model of human capital accounts for $50.17 \%$ of the bank performance variability. Further, the single model of innovation speed accounts for $54.22 \%$, while the model of innovation quality accounts for $39.05 \%$.

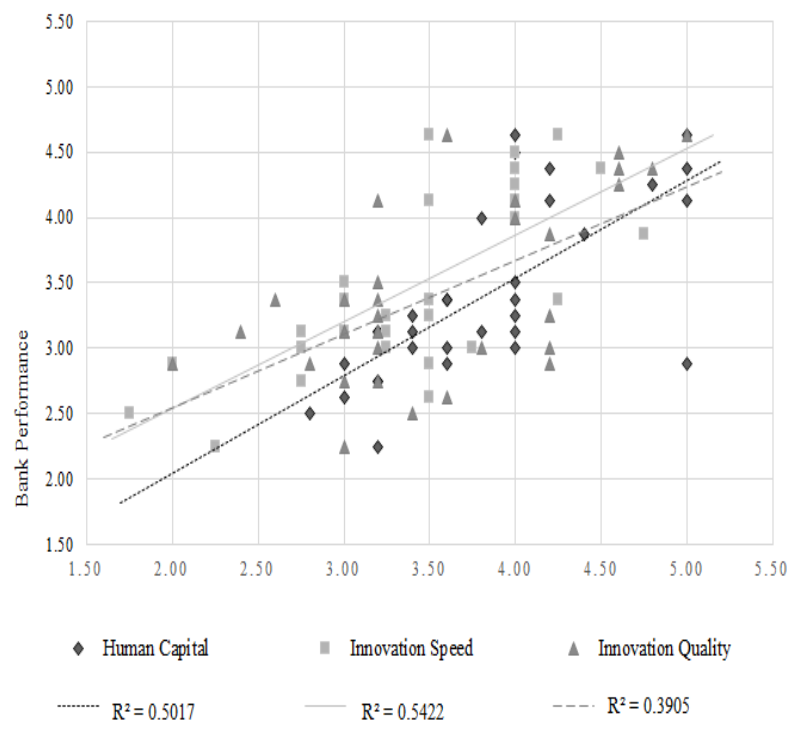

Figure 2. Bank Performance with Respect to Human Capital, Innovation Speed, and Innovation Quality

To combine the results in one comprehensive model, we used backward multiple linear regression analysis. The results are shown in Table 2 .

Table 2

Multiple Backwards Regression Models of Bank Performance

\begin{tabular}{|c|c|c|c|c|}
\hline Predictors & Model 1 & Model 2 & Model 3 & Model 4 \\
\hline Constant (Intercept) & 0.785 & 0.440 & 0.450 & 0.062 \\
\hline Human capital & $0.502 * * *$ & $0.505^{* * *}$ & $0.516 * * *$ & $0.477 * * *$ \\
\hline Innovation speed & $0.385^{*}$ & $0.401 * *$ & $0.441 * * *$ & $0.459 * * *$ \\
\hline Innovation quality & 0.071 & 0.061 & 1 & 1 \\
\hline Years of work & -0.013 & -0.014 & -0.013 & 1 \\
\hline Number of employees & 0.001 & I & 1 & 1 \\
\hline \multicolumn{5}{|l|}{ Model fit statistics } \\
\hline $\mathrm{F}$ & $12.743 * * *$ & $16.463 * * *$ & $22.555 * * *$ & $33.138 * * *$ \\
\hline $\mathrm{R}^{2}$ & 0.710 & 0.709 & 0.707 & 0.699 \\
\hline Adjusted $\mathrm{R}^{2}$ & 0.654 & 0.666 & 0.676 & 0.675 \\
\hline
\end{tabular}

Note: *Sig. at the level $p<0.05 ; * *$ Sig. at the level $p<0.01 ; * * *$ Sig. at the level $p<0.001$.

The backward multiple linear regression model was executed in four steps. The first step included three hypothesized and two control variables. The initial model explained $65.4 \%$ of the variability of the dependent variable bank performance. Each following step excluded the variable that was shown to be the least significant from the model. The final model has kept the two hypothesized variables - human capital and innovation speed. It explains $67.5 \%$ of the variability of the bank performance $\left(\mathrm{AdjR}^{2}=\right.$ $0.675 ; \mathrm{F}=33.138 ; \mathrm{p}<0.001)$, with both variables significant at the 0.01 level. 


\section{Discussion}

In our study, we focus on tackling the relationships among the perception of human capital, innovations, and performance in the banking industry.

The study foremost examined the general managers' perception of the human capital influence on bank performance. Our findings show that there is a strong and positive relationship between the managerial perception of human capital and bank performance $(r=0.708)$ and that human capital significantly influences bank performance in the final regression model. It was important to confirm this assertion since global companies, including banks, make substantial investments in human capital, expecting better performance results. Previous studies also point out that human capital development leads to better performance (Aledo Ruiz et al., 2017). Focused on the performance observed by the bank managers, our results support the association between human capital and other quantitative performance measures, such as return on equity and return on assets (Hanley et al., 1997; Meles et al., 2016). Our findings are similar to studies which show that investments in human capital can lead to positive individual and organizational performance (Crook et al., 2011; Subramony, Krause, Norton \& Burns, 2008), or that it is a crucial factor for success in service-oriented organizations because everything is based on trust (Hartmann \& Slapnicar, 2009).

According to some authors, the key and most valuable skills for solving complex problems are creative thinking, idea evaluation, and visioning (Mumford, Todd, Higgs \& McIntosh, 2017). We extend their research pointing out that people with specific knowledge, skills, and abilities can contribute to innovation management and consequently provide long-lasting success. Our findings show a positive and moderate relationship between managers' perception of human capital and innovation speed $(\mathrm{r}=0.502)$, as well as between human capital and innovation quality $(r=0.514)$. These results had initially been envisioned, to a certain extent. It has previously been shown that human capital is one of the key innovation factors (Delgado-Verde et al., 2016; Rezende et al., 2017), as well as that it is crucial for competitiveness, efficiency, and innovation (Cebi et al., 2010; Firer \& Stainbank, 2003; Milosevic et al., 2018; Pew Tan et al., 2007). Additionally, our findings are in line with Soewarno and Tjahjadi (2020) who argue that organizations that invest in human capital have a better prospect for innovations as well as R\&D improvements. Our research extends the literature regarding human capital and innovations in specific banking industries. More precisely, we extended the previous findings showing that human capital is positively correlated with both innovation speed and quality.

Previous research show that the innovations are important drivers of competitive advantages and stable a market position (Zaleska \& Kondraciuk, 2019). Our paper has recognized that innovations are important for bank performance improvement. We expanded on the research that point out that innovations are a crucial factor for success within the banking industry (Zaleska \& Kondraciuk, 2019), by addressing these concepts from the managerial point of view. Our findings show that there is a positive and strong correlation between innovation speed and bank performance $(\mathrm{r}=0.736, \mathrm{p}<0.001)$, and a positive moderate correlation between innovation quality and bank performance $(\mathrm{r}=0.625)$. This was in line with Wang and Wang (2012) who found a positive impact of innovation speed and quality on performance. However, even if the relationship between innovation quality and bank performance was shown to be positive and significant, innovation quality was excluded from the equation in our final regression model, showing that only innovation speed together with human capital significantly influences bank performance. These two variables account for $67.5 \%$ of the variability of bank performance. This is presumably due to the fact that the large percentage of the variability in bank performance explained by the innovation quality is already encompassed by the two significant variables in the model. Moreover, it is more likely that a large percentage of the variability explained by the innovation quality is already encompassed by the innovation speed. This leads us to the conclusion that the influence of innovation speed on bank performance is more decisive for the success of banks than the influence of its quality. Even though innovation quality is still important for banks, their success is sooner driven by innovation agility and readiness. Thus, even though numerous studies (Shinkle \& Suchard, 2019; Terziovski, 2010) analyze the relationship between innovations and performance, we add to this stream of research arguing that innovation speed should be one of the top priorities in banks.

While there is a growing body of literature that discusses human capital, innovations, and performance within different industries (Cabagnols \& Le Bas, 2002; Solow, 1957), we take into account the unstable Serbian banking industry. The homogeneity of the industry and very high competition are very specific for the Serbian banking market. Through this paper and our findings, similarly to Nguyen (2020), we offer additional insight into the banking industry in developing countries.

The research presented in this paper has certain limitations that should be considered. First, we again need to stress that the variables are measured based on the perceptions of CEOs and general managers who have a certain degree of subjectivity. Future research could look at more objective indicators of the performance or consider its different aspects (e.g., financial and non-financial), and it could be directed towards linking the perception and notion on human capital, innovation, and performance with the various quantitative measurable performance metrics. Second, our sample counts 32 respondents, and, even though the sample is representative when it comes to the Serbian banking industry, it still leads to severe limitations in terms of data analysis. Future research should focus on a larger sample, preferably from other countries, sectors, and industries.

Our research also has some practical implications. Innovation depends on teamwork and employees' willingness to share knowledge and experience. Therefore, banks should invest a considerable amount of time in implementing new policies which will foster knowledge sharing among employees. Generally speaking, most of the focus should be placed on the employees, as their knowledge and practical skills shall lead to all around better performance. Well-designed training and seminars are crucial for employees' development (Bauernschuster, 
Falck \& Heblich, 2009). This paper leads to the recognition that people in the banking industry are among the most valuable resources and that they can be considered as a trigger for fostering innovation therefore leading to better performance. Other issues, such as how to reinforce the links between human capital and innovation in the banking industry, could be worth exploring in future studies. It could be fruitful to analyze the managerial and leadership skillsets that are important for making sure that innovation runs more smoothly in the banking business.

\section{Conclusion}

The model presented in this research analyzes the relationship between the managerial perception of human capital, innovation speed and quality, and their view of bank performance. Our results suggest that, from managers' point of view, human capital is critical to the success of banks, and that innovation speed is more influential than its quality.

The results indicate a strong positive correlation between human capital and bank performance $(r>0.7)$, a moderate positive correlation between human capital and innovation speed and quality $(r>0.5)$, and a strong correlation between innovation speed and bank performance $(r>0.7)$. The final regression model encompassed two hypothesized variables, human capital and innovation speed, explaining $67.5 \%$ of the variability of the bank performance.

Even though there are studies that discuss the effects of human capital and knowledge sharing on various aspects of innovation and performance (Meles et al., 2016; Ozkan et al., 2017; Wang \& Wang, 2012), previously conducted empirical research that specifically examines bank success through human capital and innovations has produced incomplete evidence. By developing and testing the presented model, we contribute to the theory and practice in several ways. Our model advances the understanding of the importance of the human factor and innovations in the service-oriented banking industry. While many papers focus on the relationship between human capital and performance, we extend prior literature by introducing the effect of innovation, where we specifically scrutinize and define differences in innovation speed and quality and their association with human capital and performance.

The significance of the results is reflected in their contribution to bank management policies and strategies. The findings of this research could provide a step towards offering more insight on how to enhance bank performance, by focusing on human capital and employees, as well as innovation agility and readiness. The created model has the potential to be implemented in other sectors and industries, which would hopefully favor the significance of the detected relationships.

\section{Appendix A}

Table A1

Scales and their Components

\begin{tabular}{|c|c|}
\hline Scale & Components \\
\hline Human capital & $\begin{array}{l}\text { Employees hold suitable work experience for accomplishing their job successfully in our company. } \\
\text { Employees of our company have excellent professional skills in their particular jobs and functions. } \\
\text { The company provides well-designed training programs. } \\
\text { The employees of our company often develop new ideas and knowledge. } \\
\text { Employees are creative in our company. }\end{array}$ \\
\hline Innovation speed & $\begin{array}{l}\text { Our Bank is quicker than key competitors in coming up with novel ideas. } \\
\text { Our Bank is quicker than key competitors in new product launching. } \\
\text { Our Bank is quicker than key competitors in new processes. } \\
\text { Our Bank is quicker than key competitors in problem-solving. }\end{array}$ \\
\hline $\begin{array}{l}\text { Innovation } \\
\text { quality }\end{array}$ & $\begin{array}{l}\text { Our Bank does better than key competitors in coming up with novel ideas. } \\
\text { Our Bank does better than key competitors in new product launching. } \\
\text { Our Bank does better than key competitors in new product development. } \\
\text { Our Bank does better than key competitors in improving processes. } \\
\text { Our Bank does better than key competitors in improving management. }\end{array}$ \\
\hline $\begin{array}{l}\text { Bank } \\
\text { performance }\end{array}$ & $\begin{array}{l}\text { Customer satisfaction at our Bank is better than that of key competitors. } \\
\text { Quality development at our Bank is better than that of key competitors. } \\
\text { Cost management at our Bank is better than that of key competitors. } \\
\text { The responsiveness of our Bank is better than that of key competitors. } \\
\text { The productivity of our Bank is better than that of key competitors. } \\
\text { The profit of our Bank is better than that of key competitors. } \\
\text { The profit growth of our Bank is better than that of key competitors. } \\
\text { Our Bank manages funds better than key competitors. }\end{array}$ \\
\hline
\end{tabular}

Note: adjusted from Wang, Sharma \& Cao (2016), and Wang \& Wang (2012)

\section{References}

Ahuja, G., \& Katila, R. (2001). Technological acquisitions and the innovation performance of acquiring firms: a longitudinal study. Strategic Management Journal, 22(3), 197-220. https://doi.org/10.1002/smj.157 
Nela Milosevic, Marina Dobrota, Veljko Dmitorvic, Sladjana Barjaktarovic-Rakocevic. Managerial Perception of Human ...

Aledo Ruiz, M. D., Gutierrez, J. O., Martinez-Caro, E., \& Cegarra-Navarro, J. G. (2017). Linking an unlearning context with firm performance through human capital. European Research on Management and Business Economics, 23(1), 16-22. https://doi.org/10.1016/j.iedeen.2016.07.001

Amrin, A., \& Nurlanova, N. (2020). Innovation Activity: Localization, New Trends and Assessment Methods. Engineering Economics, 31(2), 134-144. https://doi.org/10.5755/j01.ee.31.2.21501

Armstrong, J. S., \& Overton, T. S. (1977). Estimating Nonresponse Bias in Mail Surveys. Journal of Marketing Research, 14(3), 396. https://doi.org/10.2307/3150783

Asiaei, K., \& Jusoh, R. (2017). Using a robust performance measurement system to illuminate intellectual capital. International Journal of Accounting Information Systems, 26, 1-19. https://doi.org/10.1016/j.accinf.2017.06.003

Bagozzi, R. P., \& Yi, Y. (1990). Assessing method variance in multitrait-multimethod matrices: The case of self-reported affect and perceptions at work. Journal of Applied Psychology, 75(5), 547-560. https://doi.org/10.1037/0021-9010.75.5.547

Bauernschuster, S., Falck, O., \& Heblich, S. (2009). Training and Innovation. Journal of Human Capital, 3(4), $323-353$. https://doi.org/10.1086/653713

Becker, G. S. (1975). Human Capital: A Theoretical and Empirical Analysis with Special Reference to Education (Second Edi). National Bureau of Economic Research, Inc.

Cabagnols, A., \& Le Bas, C. (2002). Differences in the Determinants of Product and Process Innovations: The French Case. In Innovation and Firm Performance (pp. 112-149). London: Palgrave Macmillan UK. https://doi.org/10.10 57/9780230595880 6

Cabrilo, S., Uzelac, Z., \& Cosic, I. (2009). Researching indicators of organizational intellectual capital in Serbia. Journal of Intellectual Capital, 10(4), 573-587. https://doi.org/10.1108/14691930910996652

Campbell, B. A., Coff, R., \& Kryscynski, D. (2012). Rethinking Sustained Competitive Advantage from Human Capital. Academy of Management Review, 37(3), 376-395. https://doi.org/10.5465/amr.2010.0276

Cebi, F., Aydin, O. F., \& Gozlu, S. (2010). Benefits of Knowledge Management in Banking. Journal of Transnational Management, 15(4), 308-321. https://doi.org/10.1080/15475778.2010.525486

Chen, C.-J., \& Huang, J.-W. (2009). Strategic human resource practices and innovation performance — The mediating role of knowledge management capacity. Journal of Business Research, 62(1), 104-114. https://doi.org/10.1016/ j.jbusres.2007.11.016

Chen, Y.-S., Hsu, J. C. S., Huang, M.-T., \& Yang, P.-S. (2013). Quality, Size, and Performance of Audit Firms. The International Journal of Business and Finance Research, 7(5), 89-105.

Chowdhury, S., Schulz, E., Milner, M., \& Van De Voort, D. (2014). Core employee based human capital and revenue productivity in small firms: An empirical investigation. Journal of Business Research, 67(11), 2473-2479. https://doi.org/10.1016/j.jbusres.2014.03.007

Cinjarevic, M., Tatic, K., \& Avdic, A. (2010). An Integrated Model of Price, Service Quality, Satisfaction and Loyalty: An Empirical Research in the Banking Sector of Bosnia and Herzegovina. Economic Research-Ekonomska Istrazivanja, 23(4), 142-161. https://doi.org/10.1080/1331677X.2010.11517439

Cornaggia, J., Mao, Y., Tian, X., \& Wolfe, B. (2015). Does banking competition affect innovation? Journal of Financial Economics, 115(1), 189-209. https://doi.org/10.1016/j.jfineco.2014.09.001

Cortina, J. M. (1993). What is coefficient alpha? An examination of theory and applications. Journal of Applied Psychology, 78(1), 98-104. https://doi.org/10.1037/0021-9010.78.1.98

Crook, T. R., Todd, S. Y., Combs, J. G., Woehr, D. J., \& Ketchen, D. J. (2011). Does human capital matter? A meta-analysis of the relationship between human capital and firm performance. Journal of Applied Psychology, 96(3), 443-456. https://doi.org/10.1037/a0022147

Damanpour, F. (1991). Organizational innovation: A meta-analysis of effects of determinants and moderators. Academy of Management Journal, 34(3), 555-590. https://doi.org/10.2307/256406

Delgado-Verde, M., Martin-de Castro, G., \& Amores-Salvado, J. (2016). Intellectual capital and radical innovation: Exploring the quadratic effects in technology-based manufacturing firms. Technovation, 54, 35-47. https://doi.org/10.1016/ j.technovation.2016.02.002

DeVellis, R. F. (2011). Scale Development: Theory and Applications (Applied Social Research Methods) (Third edit). SAGE Publications, Inc.

Doty, D. H., \& Glick, W. H. (1998). Common Methods Bias: Does Common Methods Variance Really Bias Results? Organizational Research Methods, 1(4), 374-406. https://doi.org/10.1177/109442819814002

Ege, A., \& Ege, A. Y. (2019). How to Create a Friendly Environment for Innovation? A Case for Europe. Social Indicators Research, 144(1), 451-473. https://doi.org/10.1007/s11205-018-2039-4 
Espinoza-Loayza, V., Salas-Tenesaca, E.-E., \& Samaniego-Namicela, A. (2019). Banking Industry Innovation. In C.-F. F. Tunez-Lopez M., Martinez-Fernandez VA., Lopez-Garcia X., Ruas-Araujo X. (Ed.), Communication: Innovation \& Quality. Studies in Systems, Decision and Control, vol 154 (pp. 463-476). Springer. https://doi.org/10.1007/978-3-31991860-0_28

European Commission. (2018). Smarter, greener, more inclusive? - Indicators to support the Europe 2020 strategy: 2018 edition. Retrieved from https://doi.org/10.2785/170012

Firer, S., \& Stainbank, L. (2003). Testing the relationship between intellectual capital and a company's performance: Evidence from South Africa. Meditari Accountancy Research, 11(1), 25-44. https://doi.org/10.1108/1022252 9200300003

Garcia-Morales, V. J., Llorens-Montes, F. J., \& Verdu-Jover, A. J. (2008). The Effects of Transformational Leadership on Organizational Performance through Knowledge and Innovation. British Journal of Management, 19(4), $299-319$. https://doi.org/10.1111/j.1467-8551.2007.00547.x

Gurbuz, S., \& Mert, I. S. (2011). Impact of the strategic human resource management on organizational performance: evidence from Turkey. The International Journal of Human Resource Management, 22(8), $1803-1822$. https://doi.org/10.1080/09585192.2011.565669

Haner, U.-E. (2002). Innovation quality-a conceptual framework. International Journal of Production Economics, 80(1), 3137. https://doi.org/10.1016/S0925-5273(02)00240-2

Hanley, C. A., Suter, M. P., \& Cocheo, S. (1997). Banking's Top Performers. ABA Banking Journal, 89(7), 36-40.

Hartmann, F., \& Slapničar, S. (2009). How formal performance evaluation affects trust between superior and subordinate managers. Accounting, Organizations and Society, 34(6-7), 722-737. https://doi.org/10.1016/j.aos.2008.11.004

Heirman, A., \& Clarysse, B. (2007). Which Tangible and Intangible Assets Matter for Innovation Speed in Start-Ups? Journal of Product Innovation Management, 24(4), 303-315. https://doi.org/10.1111/j.1540-5885.2007.00253.x

Huselid, M. A. (1995). The Impact of Human Resource Management Practices On Turnover, Productivity, And Corporate Financial Performance. Academy of Management Journal, 38(3), 635-672. https://doi.org/10.5465/256741

Janger, J., Schubert, T., Andries, P., Rammer, C., \& Hoskens, M. (2017). The EU 2020 innovation indicator: A step forward in measuring innovation outputs and outcomes? Research Policy, 46(1), 30-42. https://doi.org/10.10 16/j.respol.2016.10.001

Jiang, K., Lepak, D. P., Hu, J., \& Baer, J. C. (2012). How Does Human Resource Management Influence Organizational Outcomes? A Meta-analytic Investigation of Mediating Mechanisms. Academy of Management Journal, 55(6), 12641294. https://doi.org/10.5465/amj.2011.0088

Jokipii, T., \& Monnin, P. (2013). The impact of banking sector stability on the real economy. Journal of International Money and Finance, 32, 1-16. https://doi.org/10.1016/j.jimonfin.2012.02.008

Kahn, K. B. (2018). Understanding innovation. Business Horizons, 61(3), 453-460. https://doi.org/10.1016/ j.bushor.2018.01.011

Kline, P. (2013). Handbook of Psychological Testing. Routledge. https://doi.org/10.4324/9781315812274

Kondratiuk-Nierodzinska, M. (2016). Innovation capabilities in EU countries: have Central and Eastern European countries been catching up? Journal of Business Economics and Management, 17(5), 765-779. https://doi.org/10.3846/16111699. 2015.1114016

Koutsomanoli-Filippaki, A., Margaritis, D., \& Staikouras, C. (2009). Efficiency and productivity growth in the banking industry of Central and Eastern Europe. Journal of Banking \& Finance, 33(3), 557-567. https://doi.org/10.1016/ j.jbankfin.2008.09.009

Liu, C.-H. (2017). The relationships among intellectual capital, social capital, and performance - The moderating role of business ties and environmental uncertainty. Tourism Management, 61, 553-561. https://doi.org/10.1016/ j.tourman.2017.03.017

Lopez-Cabrales, A., Valle, R., \& Herrero, I. (2006). The contribution of core employees to organizational capabilities and efficiency. Human Resource Management, 45(1), 81-109. https://doi.org/10.1002/hrm.20094

Masum, A. K. M., Azad, M. A. K., \& Beh, L.-S. (2016). The role of human resource management practices in bank performance. Total Quality Management \& Business Excellence, 27(3-4), 382-397. https://doi.org/10.1080/ 14783363.2014.1002762

Meles, A., Porzio, C., Sampagnaro, G., \& Verdoliva, V. (2016). The impact of the intellectual capital efficiency on commercial banks performance: Evidence from the US. Journal of Multinational Financial Management, 36, 64-74. https://doi.org/10.1016/j.mulfin.2016.04.003

Milosevic, N., Dobrota, M., \& Barjaktarovic Rakocevic, S. (2018). Exploring the impact of intellectual capital components on project performance. European Project Management Journal, 8(2), 43-51. https://doi.org/10.18485/ epmj.2018.8.2.6

Mumford, M. D., Todd, E. M., Higgs, C., \& McIntosh, T. (2017). Cognitive skills and leadership performance: The nine critical skills. The Leadership Quarterly, 28(1), 24-39. https://doi.org/10.1016/j.leaqua.2016.10.012

Nguyen, V. C. (2020). Human capital, capital structure choice and firm profitability in developing countries: An empirical study in Vietnam. Accounting, 127-136. https://doi.org/10.5267/j.ac.2019.11.003 
Nela Milosevic, Marina Dobrota, Veljko Dmitorvic, Sladjana Barjaktarovic-Rakocevic. Managerial Perception of Human ...

Nienaber, A. M., Schewe, G., Zamantili Nayir, D., \& Holtgrave, M. (2019). Knowledge comes but wisdom lingers! Learning orientation as the decisive factor for translating social capital into organisational innovativeness and performance in Turkey. European J. of International Management, 1(1), 1. https://doi.org/10.1504/EJIM.2019. 10018106

Otoo, F. N. K. (2019). Human resource development (HRD) practices and banking industry effectiveness. European Journal of Training and Development, 43(3/4), 250-271. https://doi.org/10.1108/EJTD-07-2018-0068

Ozkan, N., Cakan, S., \& Kayacan, M. (2017). Intellectual capital and financial performance: A study of the Turkish Banking Sector. Borsa Istanbul Review, 17(3), 190-198. https://doi.org/10.1016/j.bir.2016.03.001

Pew Tan, H., Plowman, D., \& Hancock, P. (2007). Intellectual capital and financial returns of companies. Journal of Intellectual Capital, 8(1), 76-95. https://doi.org/10.1108/14691930710715079

Podsakoff, P. M., MacKenzie, S. B., Lee, J. Y., \& Podsakoff, N. P. (2003). Common method biases in behavioral research: A critical review of the literature and recommended remedies. Journal of Applied Psychology, 88(5), 879-903. https://doi.org/10.1037/0021-9010.88.5.879

Podsakoff, P. M., MacKenzie, S. B., \& Podsakoff, N. P. (2012). Sources of Method Bias in Social Science Research and Recommendations on How to Control It. Annual Review of Psychology, 63(1), 539-569. https://doi.org/10.1146/ annurevpsych-120710-100452

Prokop, V., \& Stejskal, J. (2017). Different approaches to managing innovation activities: An analysis of strong, moderate, and modest innovators. Engineering Economics, 28(1), 47-55. https://doi.org/10.5755/j01.ee.28.1.16111

Rajapathirana, R. P. J., \& Hui, Y. (2018). Relationship between innovation capability, innovation type, and firm performance. Journal of Innovation \& Knowledge, 3(1), 44-55. https://doi.org/10.1016/j.jik.2017.06.002

Rezende, J. F., Correia, A. A., \& Gomes, B. A. (2017). The intellectual capital and the creation of value in research units linked to the Brazilian Ministry of Science Technology and Innovation. RAI Revista de Administração e Inovação, 14(3), 199215. https://doi.org/10.1016/j.rai.2017.03.010

Ribau, C. P., Moreira, A. C., \& Raposo, M. (2019). The role of exploitative and exploratory innovation in export performance: an analysis of plastics industry SMEs. European J. of International Management, 13(2), 224. https://doi.org/10.150 4/EJIM.2019.098149

Rouvinen, P. (2002). R\&D_Productivity Dynamics: Causality, Lags, and 'Dry Holes.' Journal of Applied Economics, 5(1), 123-156. https://doi.org/10.1080/15140326.2002.12040573

Roy, R., \& Shijin, S. (2018). Dissecting anomalies and dynamic human capital: The global evidence. Borsa Istanbul Review, 18(1), 1-32. https://doi.org/10.1016/j.bir.2017.08.005

Rue, L., Byars, L., \& Ibrahim, N. (2012). Management: Skills \& Application (14 edition). McGraw-Hill Education.

Sakalas, A., \& Liepe, Z. (2013). Human Capital System Evaluation in the Context of the European Union Countries. Engineering Economics, 24(3). https://doi.org/10.5755/j01.ee.24.3.2787

Samagaio, A., \& Rodrigues, R. (2016). Human capital and performance in young audit firms. Journal of Business Research, 69(11), 5354-5359. https://doi.org/10.1016/j.jbusres.2016.04.137

Santos-Vijande, M. L., Lopez-Sanchez, J. A., \& Gonzalez-Mieres, C. (2012). Organizational learning, innovation, and performance in KIBS. Journal of Management \& Organization, 18(6), 870-904. https://doi.org/10.1017/ S18333 $6720000050 \mathrm{X}$

Santos, D. F. L., Basso, L. F. C., Kimura, H., \& Kayo, E. K. (2014). Innovation efforts and performances of Brazilian firms. Journal of Business Research, 67(4), 527-535. https://doi.org/10.1016/j.jbusres.2013.11.009

Schmid, S., \& Altfeld, F. (2018). International work experience and compensation: Is more always better for CFOs? European Management Journal, 36(4), 530-543. https://doi.org/10.1016/j.emj.2017.11.001

Schumpeter, J. A. (1934). The Theory of Economic Development: An Inquiry into Profits, Capital, Credit, Interest and the Business Cycle.

Shankar, K., \& Ghosh, S. (2013). A Theory of Worker Turnover and Knowledge Transfer in High-Technology Industries. Journal of Human Capital, 7(2), 107-129. https://doi.org/10.1086/671188

Shanker, R., Bhanugopan, R., van der Heijden, B. I. J. M., \& Farrell, M. (2017). Organizational climate for innovation and organizational performance: The mediating effect of innovative work behavior. Journal of Vocational Behavior, 100, 6777. https://doi.org/10.1016/j.jvb.2017.02.004

Shinkle, G. A., \& Suchard, J. A. (2019). Innovation in newly public firms: The influence of government grants, venture capital, and private equity. Australian Journal of Management, 44(2), 248-281. https://doi.org/10.1177/ 0312896218802611

Sirmon, D. G., \& Hitt, M. A. (2009). Contingencies within dynamic managerial capabilities: interdependent effects of resource investment and deployment on firm performance. Strategic Management Journal, 30(13), $1375-1394$. https://doi.org/10.1002/smj.791

Soewarno, N., \& Tjahjadi, B. (2020). Measures that matter: an empirical investigation of intellectual capital and financial performance of banking firms in Indonesia. Journal of Intellectual Capital, 21(6), 1085-1106. https://doi.org/10.1108/JIC09-2019-0225 
Solow, R. M. (1957). Technical Change and the Aggregate Production Function. The Review of Economics and Statistics, 39(3), 312. https://doi.org/10.2307/1926047

Staikouras, C., Mamatzakis, E., \& Koutsomanoli-Filippaki, A. (2008). Cost efficiency of the banking industry in the South Eastern European region. Journal of International Financial Markets, Institutions and Money, 18(5), $483-497$. https://doi.org/10.1016/j.intfin.2007.07.003

Stoica, O., Mehdian, S., \& Sargu, A. (2015). The Impact of Internet Banking on the Performance of Romanian Banks: DEA and PCA Approach. Procedia Economics and Finance, 20, 610-622. https://doi.org/10.1016/S2212-5671(15)00115-X

Subramony, M., Krause, N., Norton, J., \& Burns, G. N. (2008). The relationship between human resource investments and organizational performance: A firm-level examination of equilibrium theory. Journal of Applied Psychology, 93(4), 778788. https://doi.org/10.1037/0021-9010.93.4.778

Subramony, M., Segers, J., Chadwick, C., \& Shyamsunder, A. (2018). Leadership development practice bundles and organizational performance: The mediating role of human capital and social capital. Journal of Business Research, 83, 120-129. https://doi.org/10.1016/j.jbusres.2017.09.044

Tabacco, G. A. (2015). Does competition spur innovation? Evidence from labor productivity data for the banking industry. Economics Letters, 132, 45-47. https://doi.org/10.1016/j.econlet.2015.04.020

Terziovski, M. (2010). Innovation practice and its performance implications in small and medium enterprises (SMEs) in the manufacturing sector: a resource-based view. Strategic Management Journal, n/a-n/a. https://doi.org/10. 1002/smj.841

Ucar, E. (2018). Local creative culture and corporate innovation. Journal of Business Research, 91, 60-70. https://doi.org/10.1016/j.jbusres.2018.05.040

Vives, X. (2019). Competition and stability in modern banking: A post-crisis perspective. International Journal of Industrial Organization, 64, 55-69. https://doi.org/10.1016/j.ijindorg.2018.08.011

Wang, S., Chen, L., \& Xiong, X. (2019). Asset bubbles, banking stability and economic growth. Economic Modelling, 78, 108117. https://doi.org/10.1016/j.econmod.2018.08.014

Wang, Z., Sharma, P. N., \& Cao, J. (2016). From knowledge sharing to firm performance: A predictive model comparison. Journal of Business Research, 69(10), 4650-4658. https://doi.org/10.1016/j.jbusres.2016.03.055

Wang, Z., \& Wang, N. (2012). Knowledge sharing, innovation and firm performance. Expert Systems with Applications, 39(10), 8899-8908. https://doi.org/10.1016/j.eswa.2012.02.017

Wang, Z., Wang, N., \& Liang, H. (2014). Knowledge sharing, intellectual capital and firm performance. Management Decision, 52(2), 230-258. https://doi.org/10.1108/MD-02-2013-0064

$\mathrm{Wu}, \mathrm{H}$. Y. (2012). Constructing a strategy map for banking institutions with key performance indicators of the balanced scorecard. Evaluation and Program Planning, 35(3), 303-320. https://doi.org/10.1016/j.evalprogplan.2011.11.009

Yen, Y. F. (2013). The impact of bank's human capital on organizational performance: How innovation influences performance. Innovation, 15(1), 112-127. https://doi.org/10.5172/impp.2013.15.1.112

Zaleska, M., \& Kondraciuk, P. (2019). Theory and practice of innovation development in the banking sector. Financial Sciences, 24(2), 76-87. https://doi.org/10.15611/fins.2019.2.06

\section{Authors' Biographies}

Nela Miloševic is a researcher and teaching assistant at the University of Belgrade, Faculty of Organizational Sciences. Her main fields of interest are managerial accounting, behavioral sciences and bank management. Nela Miloševic is a PhD candidate at KU Leuven and a visiting researcher at Maastricht University and Tilburg University. She gained professional experience through number of national and international research projects, and published numerous papers in scientific journals, conference proceedings, and monographs. Nela Miloševic gained practical knowledge working as an academic fellow in several banks in Serbia.

Marina Dobrota is an associate professor at the University of Belgrade - Faculty of Organizational Sciences, where she completed her $\mathrm{PhD}$ thesis in the field of Operational Research and Computational Statistics. She has published more than 70 research papers in scientific journals, conference proceedings, and monographs, both international and national. Her research focus is in Composite Indicators, Econometric Modeling, and Data Science. Her research interests include Statistical inference, Data Analysis, Data Mining, and Time Series Analysis. She is a member of International Statistical Institute (ISI).

Veljko Dmitrovic is an associate professor at the Faculty of Organizational Sciences, University of Belgrade, at the Department of Financial Management and Accounting. He finished his PhD studies at the Faculty of Organizational Sciences. He achieved his MSc degree in Financial Management at the Faculty of Organizational Sciences, University of Belgrade, BSc and MA degrees in Marketing Management at the Faculty of Economics in Subotica, University of Novi Sad. So far he has authored and coauthored more than 100 papers published in international and national journals and conferences. He has been involved in several research projects. Before the academic career he gained practical experience working for five years in a.d. "Fidelinka" Subotica. His research interests are accounting, financial and nonfinancial reporting. 
Nela Milosevic, Marina Dobrota, Veljko Dmitorvic, Sladjana Barjaktarovic-Rakocevic. Managerial Perception of Human ...

Slađana Barjaktarovic Rakocevic is an associate professor in the Department of Financial Management at the University of Belgrade, Faculty of Organizational Sciences. Her main fields of research interest are financial institutions management, financial markets, and managerial accounting. She was a visiting lecturer at the University of Maribor and also was on study visits in the United States at the University of Illinois and the New York Stock Exchange. She has published more than 100 research papers in scientific journals, conference proceedings, and monographs, both international and national. Sladjana is one of the editors of the international monograph „Innovative Management and Firm Performance - An Interdisciplinary Approach" published by Palgrave Macmillan form the UK.

The article has been reviewed.

Received in June 2020; accepted in October 2021.

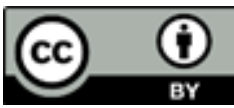

This article is an Open Access article distributed under the terms and conditions of the Creative Commons Attribution 4.0 (CC BY 4.0) License (http://creativecommons.org/licenses/by/4.0/). 